\title{
Contradictions of institutional and economic environment: Experience of Kazakhstan
}

\author{
Madina Tulegenova, Zhansaya Temerbulatova, \\ Aifer Baimukhametova, Dinara Rakhmatullayeva
}

\begin{abstract}
A B S T R A C T
Objective: The purpose of the study is to assess the quality of economic growth in Kazakhstan. An attempt has been made to provide an analysis of the institutional and economic environment and an econometric assessment of the real indicators of the country's development.

Research Design \& Methods: To assess the degree of influence of certain indicators on economic growth, a regression analysis was carried out. For this, data were collected from 15 countries for 2000-2018. Since the sample combines temporal and spatial data, a panel data regression model was built to analyze the effect of the considered explanatory variables on GDP. To study a model with these characteristics, two different models can be used: a fixed effects (FE) model and a random effects (RE) model.

Findings: Based on the historical and logical analysis of theoretical and methodological approaches to the study of economic development and the constructed regression model of panel data, it is shown that an increase in the level of indicators selected in official statistics has a small effect on economic growth, that is, there is a discrepancy between target indicators government programs and actual results. The institutional features of the Kazakhstani development model, which cause economic lag, are revealed.

Implications \& Recommendations: The current cyclical transition, complicated by the Covid-19 pandemic, has revealed weak links in the economies of many countries, caused by systemic contradictions accumulated over 30 years. Kazakhstan, as a country that has been building market relations only since the end of the 20th century, found itself in the grip of not only economic and political, but also institutional costs. One of the problems hindering the economic development of the nation is the contradiction between the political ambitions of the authorities and the real results of the implementation of state programs, the loss of public confidence.

Contribution \& Value Added: The country's development prospects are primarily predetermined by the state's ability to solve accumulated problems. Therefore, it is important to identify them, solve, and then predict the real parameters of the country's development. The importance of such a methodological approach is noted by scientists from the post-Soviet countries, who study the factors that hinder the development of these countries.

Article type: conceptual article

Keywords: business environment; institutions; institutional economics; new markets; real economic growth; social inequality; quality of life of the population

JEL codes: $\quad$ 011, 043, C23

Received: 17 May $2021 \quad$ Revised: 4 September $2021 \quad$ Accepted: 30 September 2021
\end{abstract}

\section{Suggested citation:}

Tulegenova, M., Temerbulatova, Z., Baimukhametova, A., \& Rakhmatullayeva, D. (2021). Contradictions of institutional and economic environment: Experience of Kazakhstan. International Entrepreneurship Review, 7(4), 75-88. https://doi.org/10.15678/IER.2021.0704.06

\section{INTRODUCTION}

For thirty years of sovereign development, Kazakhstan has become recognizable not only as country rich in natural resources, but also due to the achievements of talented youth at the world level in sports, culture, art, as well as ambitious statements of the authorities (Sansyzbayeva et. al., 2020). The international community is convinced of the rich competitive opportunities of society and high human 
potential. However, researchers cannot fail to notice the limited transformation of society's capabilities into competitive advantages of the state: the real socio-economic state of the country is "veiled" in official statistics. The results of many adopted state development programs of the country remain as expected. Most investments, including borrowed ones, do not pay off. The real transparency of decisions and the process of using budgetary resources are limited. The current institutional and economic environment has a contradictory impact on business development, and accordingly, entrepreneurs tend to behave opportunistically (Głodowska, Pera \& Wach, 2016). A model of a simulated economy emerges. In the annual program documents, the country's leadership announces strategic tasks, the solution of which should ensure an increase in the quality of life of the population and the international competitiveness of the economy. The main arguments for optimism are the improvement of macroeconomic indicators and government support for business and the population at the expense of budget funds. At the same time, state authorized bodies also report on huge amounts of funds invested by oligarchs abroad, embezzlement of state budget funds.

The aim of the study is to assess the quality of economic growth in Kazakhstan. An attempt is made to provide an analysis of the discrepancies in expectations stated in government programs and real indicators of economic development in Kazakhstan.

The article is structured as follows. The first section of the Introduction reflects the relevance, purpose and significance of the study. In the second section, a literature review is conducted, where the difference between the concepts of "economic growth" and "economic development" is considered, as well as various methodological approaches to the study of problems of economic development are presented. The third part describes the methods and data used in the article. The fourth part presents the results of the study. And in the final fifth part of the article, conclusions and recommendations are presented.

\section{LITERATURE REVIEW}

In connection with the emerging contradictions between the official indicators of economic growth and the real economic development of the country, it is necessary to clarify the difference between the concepts of "economic growth" and "economic development".

Economic growth is a quantitative indicator that reflects the dynamics of macroeconomic indicators (GDP, inflation, employment). This indicator does not reflect the impact of dynamic growth on the environment, health, birth rate, life expectancy, education, social security of the population.

Economic development is an indicator of the quality of life, reflecting the increase in national wealth, growth in the number and expected duration of life of the population, the availability of benefits for all, legal and environmental security of life, and social progress. The world scientific community and international organizations are studying this indicator, comparing its level in different countries (Kuznets, 1946). In the post-Soviet space, the issues of the quality of life are being actively discussed in connection with the ongoing systemic transformations in the political economy and the deterioration of the living conditions of the majority of the population (Balobanov \& Golubev, 2011).

The origins of the theory of economic development come from the works of ancient thinkers: philosophers, economists, who studied the nature and factors of the wealth of peoples, the incomes of different social strata. Thus, Smith (2007), in his famous work "Research on the nature and causes of the wealth of peoples", foreseeing the physical poverty of the population in developing countries in the 21st century, "gives a lesson" to capital owners and government authorities on the distribution of the product and the determination of the minimum consumption basket of an employee: Man must always be able to exist by his labour, and his wages must at least be sufficient for his existence. Even in most cases it should slightly exceed this level; otherwise, it would be impossible for him to support his family, and the race of these workers would become extinct after the first generation. In this thought, we find an emphasis on the socio-demographic factor of economic development. Marx (2017) in the first volume of "Capital" developed it, defining labour as a commodity and proposing a formula for calculating its average daily value and a method for distributing new value to the worker's income and the capitalist's profit, which predetermined social stratification in a capitalist society. 
In the 20th century, an impetus to the study of economic development and the role of the state in this process was given by American researchers - Arthur Lewis and Theodore Schultz - laureates of the Nobel Prize in 1979 for "innovative studies of economic development as applied to the problems of developing countries". Lewis (2013) among the factors influencing real economic growth, considered institutional, associated with the existing forms of organization of a given society, with its political system and the nature of property relations. In his opinion, maintaining law and order is one of the main conditions for economic growth, and many societies fell into decay because the state was unwilling or unable to protect property owners from bandits or mobs. Schultz (1971) in his studies analyzed the reasons for the low quality of life in developing countries and the factors of the "economic miracle" of post-war Germany and Japan, substantiated that the prosperity of states wasn't based on minerals and the wealth of banks, but on educated and healthy citizens. A significant contribution to the study of the role of institutionalism in technological transformation and economic development of the countries of the non-Western world was made by such outstanding economists as De Soto (2004), Nelson \& Winter (2002), Stiglitz (1997), Todaro (1997).

In countries of an emerging market, a great contribution to the scientific school of institutionalists was made by Russian scientists such as Nureyev (2001) or Auzan (2011).

The different approaches of economic development researchers show that in this area there are many possibilities for choosing different goals.

To assess the level of economic development in the modern world, international organizations use integral measurement methods - indices. In 1979, an index of the physical quality of life was created. The Quality of Life Index is a combined indicator that measures the achievements of countries of the world and individual regions in terms of their ability to provide their residents with a prosperous life. The Index summarizes the results of subjective satisfaction with the life of citizens of different countries of the world and correlates them with objective indicators of the socio-economic well-being of residents of these countries. At the same time, the quality of life means the satisfaction of the population with their life and living conditions, based on their real various needs and interests. The Quality of Life Index is compiled on the basis of statistical analysis of nine key indicators that reflect various aspects of the quality of life of the population and is published annually within the framework of the United Nations Development Program to compare the level of economic development of countries around the world. Since 2006, the world began to define a new international measure of "Happiness" - "International Happiness Index", which takes into account the dream and desires of most people on Earth to be happy and healthy, to live a long and fulfilling life. Since 2012, the UN Sustainable Development Solutions Network has been publishing the World Happiness Report. This is a global survey in which people are asked to rate how satisfied they are with life. In 2018, residents of 156 countries participated in it. Finland, Denmark, Norway, Iceland and Netherlands were included in the top five. Kazakhstan ranked 60th and second among the CIS countries after Uzbekistan (Tulekbajewa, 2019).

A new methodological approach to the study of economic development problems in order to achieve effective results of the implementation of government programs in improving the well-being of ordinary people was developed by Banerjee, Duflo and Kremer- the 2019 Nobel Prize winners in economics (Banerjee \& Duflo, 2012). The prize was awarded "for an experimental approach to reducing global inequality". Their research is aimed at microeconomic analysis, identification of population problems. Among the basic requirements for overcoming the above-mentioned problems, scientists single out: satisfaction of basic needs (food, no fear of losing income).

Research on the factors influencing the economic growth of a country was carried out in the scientific papers of Chlebisz and Mierzejewski (2020). They suggest that an increase in the share of exports of high-tech products can increase the country's GDP and, as a result, have a positive effect on the growth of economic indicators.

Głodowska(2017) in the study attempts to substantiate the importance of supporting business environment development as a factor of economic growth in the country.

It is impossible to overestimate the role of the pandemic situation, which in many aspects affected the economic development of the world market. The negative effects of this phenomenon have been investigated by many scientists. Żak and Garncarz (2020) have identified an unprecedented decline in 
economic activity in the Scandinavian countries. The experience of the Scandinavian countries subsequently can be taken into account in world practice.

\section{RESEARCH METHODOLOGY}

In the course of the research, general scientific methods were used, such as observation, historicallogical and statistical analysis, visualization and econometric modelling. To assess the degree of influence of certain indicators on economic growth, a regression analysis was carried out. For this, data were collected from 15 countries for 2000-2018. Since the sample combines temporal and spatial data, a panel data regression model was built to analyze the effect of the considered explanatory variables on GDP. To study a model with these characteristics, two different models can be used: a fixed effects (FE) model and a random effects (RE) model. The fixed effects model examines the relationship between a predictor and outcome variables within an entity and assumes that the explanatory variables are fixed in units of observation and that fixed effects are computed from the differences within each unit over time. And random effects model is usually preferred when it is assumed that missing variables are absent or not correlated with the explanatory variables considered in the model. Using this model allow to determine unbiased estimates of the coefficients, use all available data, and generate the smallest standard errors. A significant difference between fixed and random effects is whether the unobservable individual effect includes elements that are correlated with regressors in the model.

The general equation of the econometric model is as follows:

$$
G D P_{i t}=\alpha_{i}+\beta X_{i t}+\varepsilon_{i t}
$$

where $i$ represents the countries in the sample $(i=1, \ldots, 15)$ and $t$ represents time $(t=2000, \ldots$, 2018). $G D P_{i t}$ is the dependent variable and represents GDP. $\alpha_{i}$ is the unobservable individual specific effect, and $\beta$ is the vector of coefficients associated with the independent variables. $X_{i t}$ is a vector of explanatory variables for country $i$ at time $t . \varepsilon_{i t}$ is the error value.

The dependent variable of the model is GDP, and the following were selected as explanatory variables: Life expectancy, Birth rate, Health expenditures, Education expenditures, Employment.

To assess the interdependence of variables, the Pearson correlation was estimated, which allowed to determine how proportional the variability of two variables. Correlation coefficients can be positive or negative. If an increase in one variable is associated with a decrease in another, then the correlation coefficient will be negative. A positive correlation is one in which an increase in one variable is associated with an increase in another variable.

All data used were collected from the official website of the World Bank and the Statistics Committee of the Ministry of National Economy of the Republic of Kazakhstan.

\section{RESULTS AND DISCUSSION}

\section{Real GDP growth over the years of Kazakhstan's sovereign development}

Since Kazakhstan, like all the countries of the post-Soviet space, was a dependent link in a single national economic complex, the collapse of the former Soviet Union led to the bankruptcy of the national economy. The country could survive in the first years of sovereign development only through the sale of natural resources. All subsequent years, the export of raw materials continues, maintaining the low quality of economic growth predicted by Stiglitz in the theory of the "resource curse" (Humphreys et al., 2007).

The most important indicators of economic development are GDP per capita, birth rate, life expectancy, literacy and education, health care, employment, gender balance, free time.

To assess the impact of these indicators on economic growth, an analysis of panel data was carried out. The sample contains data for 15 countries of the former Soviet Union for 2000-2018. The dependent variable in the model is GDP, and the independent variables are life expectancy, birth rate, health and education expenditures, and employment.

Using the collected panel data, 2 regression equations with fixed and random effects were constructed. The general equation adapted to the sample is described by equation (2): 


$$
\begin{gathered}
G D P_{i t}=\beta_{1} \text { Lifeexpectancy }_{i t}+\beta_{2} \text { Birthrate }_{i t}+\beta_{3} \text { Healthexp }_{i t}+\beta_{4} \text { Educationexp }_{i t} \\
+\beta_{5} \text { Employment }_{i t}+\alpha_{i}+\varepsilon_{i t}
\end{gathered}
$$

The results of econometric calculations performed using the STATA statistical software package with the dependent variable GDP are shown in Table 1.

\begin{tabular}{|c|c|c|}
\hline Independent variables & (1) & (2) \\
\hline Life expectancy & $\begin{array}{c}0.066 * * * \\
(0.007)\end{array}$ & $\begin{array}{c}0.067 * * * \\
(0.007)\end{array}$ \\
\hline Birth rate & $\begin{array}{c}0.062 * * \\
(0.008)\end{array}$ & $\begin{array}{c}0.058 * * * \\
(0,0086)\end{array}$ \\
\hline Health expenditures & $\begin{array}{c}0.026 * * * \\
(0.012) \\
\end{array}$ & $\begin{array}{c}0.026 * * \\
(0.012) \\
\end{array}$ \\
\hline Education expenditures & $\begin{array}{c}-0.026 * * * \\
(0.0049) \\
\end{array}$ & $\begin{array}{c}-0.026^{* * *} \\
(0.005)\end{array}$ \\
\hline Employment & $\begin{array}{l}0.009 * \\
(0.005) \\
\end{array}$ & $\begin{array}{c}0,011^{* *} \\
(0.005) \\
\end{array}$ \\
\hline Cons & $\begin{array}{c}4.353^{* * *} \\
(0.445) \\
\end{array}$ & $\begin{array}{c}4.318^{* * *} \\
(0.549) \\
\end{array}$ \\
\hline Individual effects & $\mathrm{FE}$ & RE \\
\hline Number of observations & 203 & 203 \\
\hline Fisher test for significance coefficients & $\begin{array}{c}F(5,183)=105,24 \\
{[0.0000]}\end{array}$ & \\
\hline R-squared & 0.742 & \\
\hline Wald statistics & & $\begin{array}{c}\text { Chi2(5) }=479.58 \\
{[0.0024]}\end{array}$ \\
\hline
\end{tabular}

Table 1. Panel regression models with dependent variable GDP

Notes: 1$)^{*}, * *, * * *$ the significance of the coefficients at $10 \%, 5 \%$ and $1 \%$ levels, respectively;

2) $F E$ - fixed effects, RE - random effects;

3) F-test for the significance of individual effects: $F(14,183)=945.57$, Prob $>F=0.0000$; Hausman test: Chi2(5) $=-8.24$, chi2<0. Source: own study.

The second column of the table shows the results of the panel data model with fixed effects using the least squares method, and the third column shows the results of the panel data model with random effects using the least squares method.

Coefficients of the variables Life expectancy, Health expenditures, Education expenditures presented in Table 1 are significant at the $1 \%$ level. The coefficient of the variable Birth rate is significant at the $5 \%$ level, and the coefficient of the variable Employment is significant at the $10 \%$ level. According to the results, the evaluated panel data regression model with fixed effects is statistically significant, as evidenced by the rather high coefficient of determination $\mathrm{R}^{2}=0.742$ and the Fisher test. In calculations for panel data with random effects, the Wald statistics Chi2 (3) serves as an indicator of the quality of the estimated models instead of the coefficient of determination. Its value given in Table 1 confirms the statistical significance of panel regression with random effects.

The F-test confirms the presence of individual effects. Since the set of countries included in the study is the same for all years, it is generally recommended to use a panel regression model with fixed effects. The Hausman test was performed, which confirmed the preference of using a panel data model with fixed effects over a panel data model with random effects.

The equation of the estimated model is as follows:

$$
\begin{aligned}
& G D P_{i t}=\begin{array}{c}
0,066 \cdot \text { Lifeexpectancy }_{i t}+ \\
(0.007)
\end{array}{ }^{0,062 \cdot \text { Birthrate }_{i t}}+{ }^{0,026 \cdot \text { Healthexp }_{i t}} \\
& --\begin{array}{c}
0.026 \cdot \text { Educationexp }_{i t} \\
(0.0049)
\end{array}+\begin{array}{c}
0.009 \text { Employment }_{i t} \\
(0.005)
\end{array}+\underset{(0.445)}{4.353}+\varepsilon_{i t}
\end{aligned}
$$

As expected, increases in Life expectancy, Birth rate, Health expenditures and Employment contribute to economic growth. The result of econometric analysis showed that $1 \%$ increase in Health 
expenditures will lead to an increase in gross domestic product by $0.026 \%$, and as a result of a $1 \%$ increase in Life expectancy, GDP will increase by only $0.066 \%$, and the estimates of the coefficients of these variables are significant at the level of $1 \%$. Also, GDP will increase by $0.009 \%$ with $1 \%$ increase in Employment.

All these indicators reflect the quality of life and well-being of the population; as a result of the analysis of panel data, it can be concluded that social support measures from the state and measures aimed at ensuring employment of the population do not have the desired effect and contribute to economic growth to a very small extent.

The methodological basis for assessing the quality of life of the population is the reliability of the analyzed indicators and an objective analysis of the social environment.

A comparative analysis of macroeconomic and socio-political indicators testifies to the contradictions of economic development in Kazakhstan. So, according to the Committee on Statistics of the Republic of Kazakhstan and the World Bank, there is an increase in the value of GDP in 2020 compared to 1993 by 7.3 times, with a decrease in the value of the national currency against the US dollar by 63 times. Figure 1 reflects the gap in the dynamics of changes in the value of GDP and the price of the national currency.

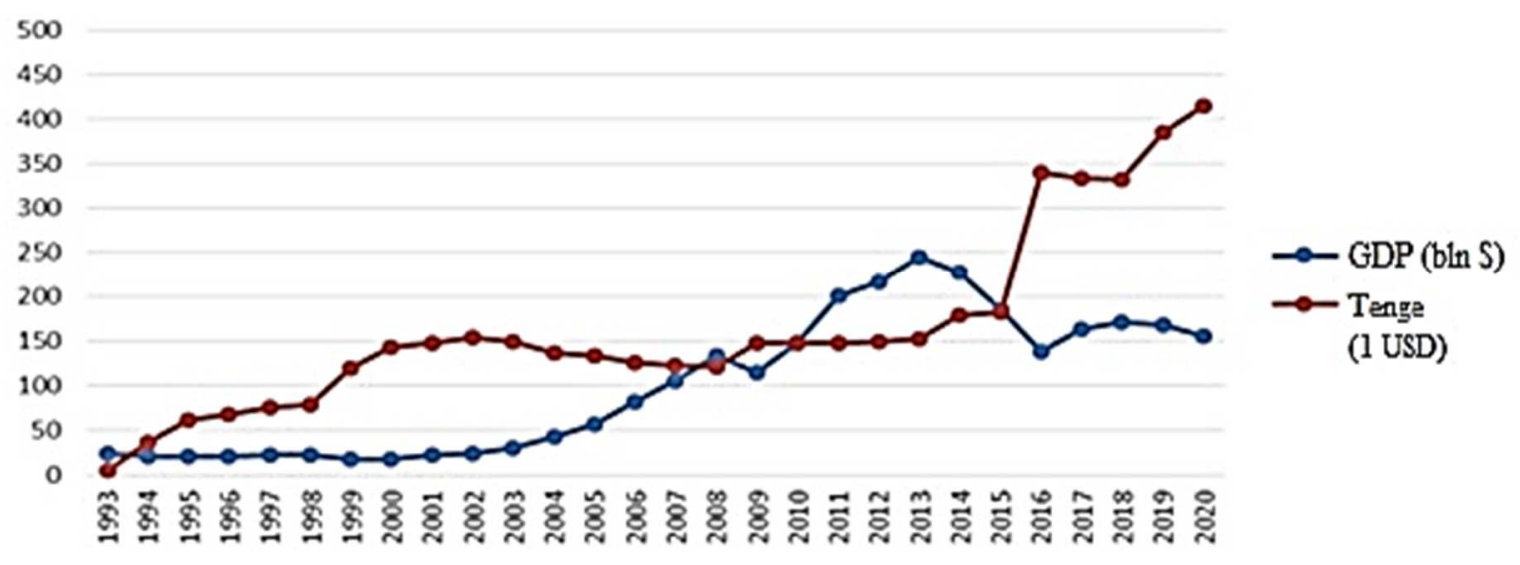

Figure 1. Dynamics of the value of GDP and the exchange rate of the national currency in Kazakhstan for 1993-2020 Source: own elaboration.

Figure 1 shows the outstripping rate of depreciation of the national currency, which reduces the real incomes of the country and the population - basic indicators of the quality of life in society. Under the influence of the volatility of oil prices, the national currency is getting cheaper, and during a pandemic it rapidly devalues, provoking an increase in the consumer price index for food, a decrease in the purchasing power of consumers, a drop in demand and bankruptcy of small, medium and large businesses. The following figure shows the interdependence of the tenge exchange rate and oil prices during the crisis years.

Figure 2 shows that GDP growth rates directly depend on the level of oil prices. The rapid increase in oil price volatility was observed during the 2008 financial crisis, when the indicator fell by $36 \%$, while the tenge fell by $22.5 \%$. A similar situation was observed in 2015 , when the fall in oil prices reached 54.5 percent, which resulted in the devaluation of the tenge by $91 \%$. The COVID-19 quarantine crisis was accompanied by record drop in oil prices by $64 \%$ and $12.5 \%$ decline in the national currency. Having analyzed the dynamics of the GDP level during the crisis years, it can be concluded that dependence on oil prices impedes a stable proportional GDP growth. The decline in GDP primarily indicates a drop in entrepreneurial activity and a weakening of the economy, since at least $70 \%$ of Kazakhstan's incomes are large businesses and SMEs.

It should be noted that even without numbers, it is clear that the counters of shopping centers reflect the dominance of imported consumer goods. The first market transformations of the political economy of the country led to the complete bankruptcy of enterprises producing the final consumer product. The liquidation of collective and state farms in the early years of the transition to a market economy led to the loss of the natural basis of industrial production of all consumer goods. At the same 
time, $70 \%$ of the backbone enterprises in the extractive industry were privatized with a high share of foreign investors. The dependence on imports of investment and consumer goods does not allow the country to get out of the rut of the catching-up economy. New industrial plants are being built and commissioned, but the batch production process remains in "standby" mode.

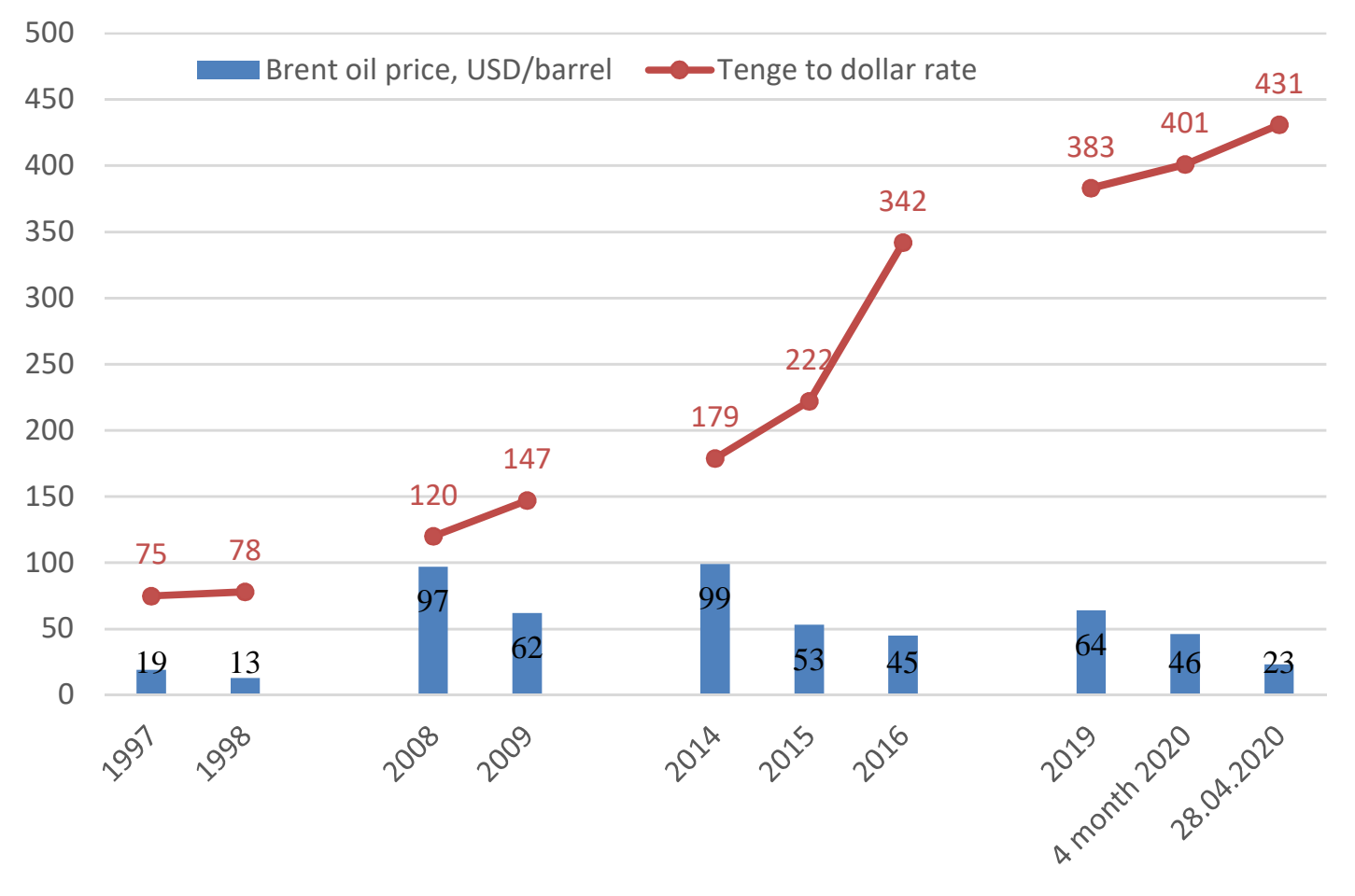

Figure 2. Dynamics of the tenge exchange rate and oil prices during the crisis years Source: own elaboration based on data from National Bank of Kazakhstan (2020) and International Energy Agency (2020).

\section{Social development indicators}

Today the quality of life is interpreted as the ability of a person to work and use income for selfdevelopment and providing the family with vital benefits that satisfy the needs according to Maslow's hierarchical model of needs.

Official statistics and research indicate a growing outflow of talented and promising young people abroad, a decrease of the population's literacy level and young people' employment by their specialty, growing social stratification, and a low quality of the new working places. This, in turn, leads to a decrease in GDP and economic growth rates.

To clarity situation it is advisable to consider how youth unemployment affects the country's GDP. For this purpose, the correlation dependence between these variables has been estimated for the last 20 years in Kazakhstan (Table 2).

Table 2. Correlation between GDP and youth unemployment in Kazakhstan, 2000-2019

\begin{tabular}{|l|l|l|l|}
\hline \multicolumn{2}{|c|}{ Variables } & GDP & Youth unemployment \\
\hline \multirow{4}{*}{ GDP } & Pearson Correlation & 1 & $-0.934^{* * *}$ \\
\cline { 2 - 4 } & $\mathrm{p}$ & & 0.000 \\
\hline & $\mathrm{N}$ & & 20 \\
\hline \multirow{3}{*}{ Youth unemployment } & Pearson Correlation & $-0.934^{* * *}$ & 1 \\
\cline { 2 - 4 } & $\mathrm{p}$ & 0.000 & \\
\cline { 2 - 4 } & $\mathrm{N}$ & 20 & \\
\hline
\end{tabular}




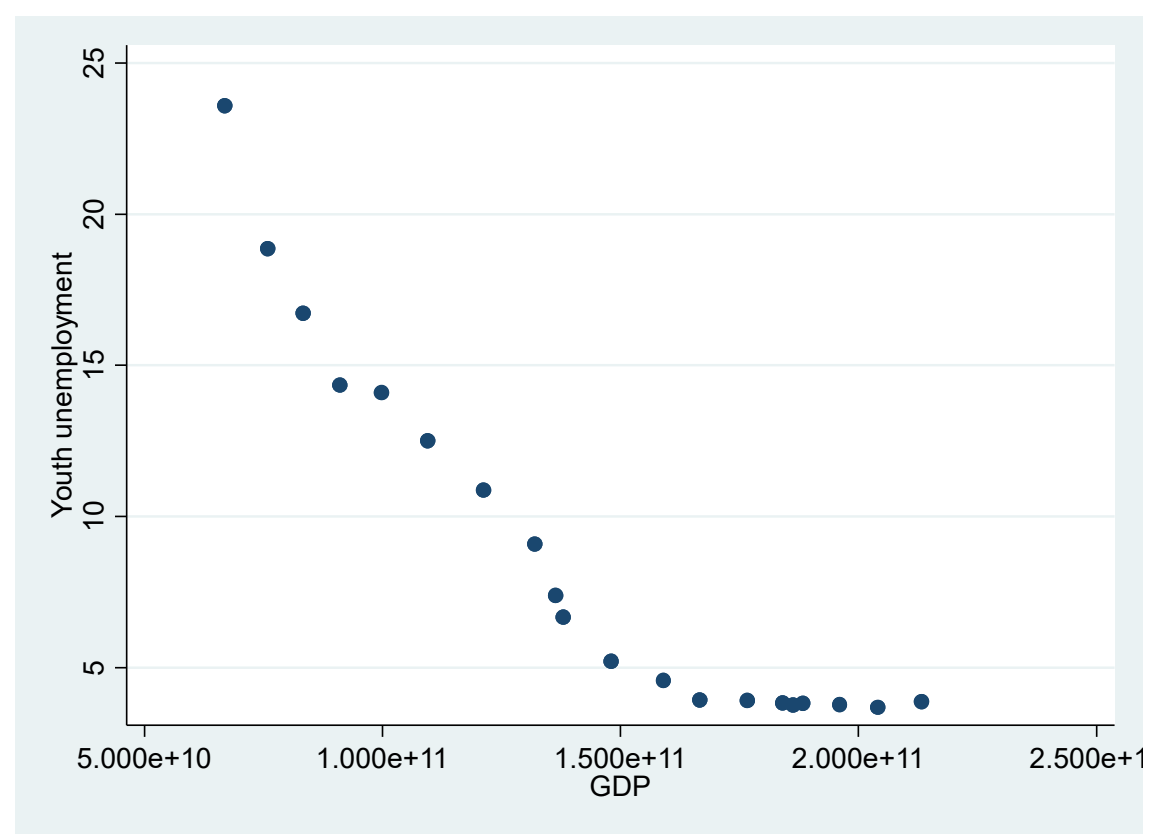

Figure 3. Scatter diagram between variables

Source: own elaboration.

Table 2 shows that the correlation between GDP and youth unemployment is very strong and significant at the $1 \%$ level $(r=-0.934, p<0.01)$, but it should be noted that there is a negative relationship between these indicators, that is, with an increase in one indicator, second decreases. The inverse relationship is clearly reflected in Figure 3. That is, due to the problem of youth employment, the country's GDP decreases.

In Kazakhstan, the unemployment rate in the second quarter of 2020 reached $5 \%$. According to IMF forecasts, unemployment in Kazakhstan will reach $7.8 \%$ by the end of 2020; during the quarantine period, the share of unemployed reached $49,8 \%$ of the total labor force (Bocharova, \&Seyit,2020). The minimum salary for wage earners in a small business is 42500 tenge (about 100 USD).

In 2020 , SMEs provided $30.8 \%$ of GDP and provides employment for 3.3 million people ( $37 \%$ of the total employed population) (Kapital, 2020).

Among those employed in small and medium-sized businesses, the share of individual entrepreneurs amounted as $65.6 \%$, legal entities of small business $-18.5 \%$, peasant farm holdings $-15.7 \%$. The share of medium-sized legal entities $-0.2 \%$ (Kursiv, 2018).

The state is taking measures to support business, introducing a preferential tax regime and ban of financial audits. However, raiding continues while the business infrastructure is not improving. Thus, the total amount spent on the introduction and implementation of the development of innovative entrepreneurship programs for the period from 2005 to 2020 is more than 900 billion tenge. Summing up the results on the reforms effectiveness that form the trajectory of the state innovative development, it was revealed that the main strategically important points for the further innovative development of the state were not met, which indicates the ineffectiveness of industrial policy. According to the recommendations of the World Bank, Kazakhstan needs to revise the existing ineffective programs to stimulate the development of entrepreneurship and to close those that are not working (Regnum, 2020).

It should be noted that during the privatization in the agrarian sector of the economy, the best lands were withdrawn from farmland. As a result, farmers are deprived of agriculture areas and pastures sufficient for livestock, equipment and fertilizers are not available due to limited income. Naturally, in such conditions, superficial measures of state support do not achieve the intended effect. Small business grows for survival. The response of the poor is manifested in opportunistic behavior: a deliberate deterioration in the material and financial conditions of life in order to obtain social support, an increase in shadow incomes, etc. Social payments to families with many children 
are accompanied by the social environment deterioration, the absence of a trusting dialogue between the state and society. There is an increase in property stratification.

The current economic crisis caused by the COVID-19 has significantly affected the economic situation in most countries of the world, having an impact primarily on small and medium-sized businesses, whose share in OECD countries is $50-60 \%$ of GDP and provides $60 \%$ of employment, in Kazakhstan the share of SMEs is $30.8 \%$. The consequences of the quarantine had a negative impact on the business sector, which is the driver of economic development in Kazakhstan. The government of Kazakhstan has applied a number of instruments to support small and medium-sized businesses, among which the most used according to the results of a study by the auditing company Ernst and Young (EY): deferred tax payments, suspension of payments on loans to financial institutions.

Also, according to the results of the EY study and the survey conducted on the effectiveness of public policy measures, it was revealed that $15 \%$ of the surveyed SMEs could not take advantage of the concessions, since the supporting measures did not apply to their field of activity, which indicates the fragmented nature of state support. A certain share of SMEs remained unattended by the state. More than half of the respondents noted significant barriers to obtaining support for their business, including: low availability of information, bureaucracy, negligence on the part of operators (Ernst \& Young, 2020).

To increase the role of SMEs in the economy of Kazakhstan, taking into account the state's desire to increase the share of entrepreneurship in GDP, it is necessary to increase the incentives and motivation of the population in order to increase labor productivity, as well as to create measures for a qualitatively new level of development of entrepreneurship, in particular innovative business, due to the technological transformation of the state.

One of the most important reasons for the failure of domestic programs, according to experts, is the incorrect formulation of measures that do not reflect specific measures to achieve the stated goals, the lack of control over each stage of project implementation, and the transparency of reports.

The key indicator of increasing the welfare of Kazakhstanis, according to the official statements of the government, is the growth of incomes of the population, but this does not take into account the fact that income withdrawals in the form of high bank interest rates are hidden behind the benefits acquired by the population through consumer loans. The provision of the population with housing is growing due to bank loans to the population, but the number of guaranteed high-quality jobs and sufficient income does not increase, which is a risk factor for loan default. The paradox is that bank services are becoming more expensive, and its stability is questionable, and in the event of a periodic default, the state pays off bank debts at the expense of the People's Welfare Fund. In 2017, bad loans reached $70 \%$ of the total volume of consumer and mortgage loans in the loan portfolio of commercial banks. In order to "rescue" the backbone commercial banks in 2017, more than 6 billion US dollars were spent from the National Welfare Fund of Kazakhstan (Masanov, 2018).The misuse of the national fund is taking place against the growing social stratification. In 2017, the share of the richest $20 \%$ of Kazakhstani people in the total income of the nation was $37.40 \%$, and the poorest $20 \%-9.80 \%$.

It turns out that "everything seems to be fine, but the confidence of the country's citizens is not seen in the future". The trust of society and business to the state and the economic romanticism of the first years of sovereign development are permanently declining. It is known that without public will, all reforms remain "on paper". This raises the question of whether the reformers are aware of which economy the state creates, real or imitated, and what are the social consequences of economic policy.

The real situation in the life of Kazakhstanis is reflected in the results of modernization of healthcare and demographic problems. So, according to the Agency for Statistics of the Republic of Kazakhstan, current expenditures on health care increased by almost 2.5 times from 594.9 billion tenge in 2010 to 1 trillion. 604.2 billion tenge. However, in the country, children under 5 still die prematurely for reasons that could have been prevented. Most children die in the first year of life (in 2016-68.4\%). So, out of 4799 children under the 5 years old, 3719 did not live to be 1 year old (Sputnik, 2017).

According to the results of 2019, the infant mortality rate in Kazakhstan increased by 5.9 percent, there are 8.4 deaths per 1000 children born. Kazakhstan ranks second among the EAEU countries in terms of mortality among children under 5 years of age (Kursiv, 2019). Another sad indicator of the 
level of social development in Kazakhstan is the increase in suicide. In 2016, there were 1756 suicides. An alarming symptom of the psychological state of society is the increase in suicide among young people. According to the Statistics Committee of the Republic of Kazakhstan (2020), in 2017, 818 suicides were registered among young people aged 14 to 28 years old.In terms of the number of child and adolescent suicides in the European Region, it is in 7th place. Government officials say the reasons for the suicides are not known. However, observations show that teenage suicide is committed mainly by children from disadvantaged families. One of the reasons is the growing gap between the rich and the poor, the growing social poverty, there is an increase in the number of dysfunctional families in which adolescent children realize the hopelessness of their situation, do not see the prospects for their lives and decide to commit suicide.

Most of all suicides are committed by persons aged 35-44 due to material despair - 899 (in 2015 775), of which men - 755 (in 2015 - 652) and women - 144 (in 2015 - 123). Adults of working age, whose psyche is oppressed by the debt burden and insolvency, see suicide as the solution. The scale of this phenomenon is growing, it was isolated cases earlier, even in the difficult years of "shock therapy" in the economy.

According to the Prosecutor General's Office, for seven months of 2020, five of which fall during the quarantine period, 2010 people committed suicide. According to the assumptions of psychologists, the reason could be a difficult financial situation and loneliness (Loginova, 2020).

The growth in incomes of the population declared by government officials does not take into account that built houses without amenities, worn out cars and small businesses are all purchased on credit, the return of which could never happen due to the lack of permanent income or improper credit agreements (Al'bekova, 2018).

\section{Dependence on the Past Trajectory of Development and the Institutional Traps of New Market States}

Methods of observation, formal deductive modeling, analysis of information from social networks were used in the research. In our opinion, institutions that are immanent to countries that have survived for many years the costs of a centralized administrative-command system, which resulted in the disintegration of the single Soviet national economy, are especially important in this study. Market transformation reforms were carried out without taking into account the peculiarities of the political structure of the one-party system and the psychology of the slave population, and representatives of power structures who monopolized the privatization process and distributed the former public property among a limited circle of former state and economic leaders. Since the countries of the post-Soviet space began to integrate into the world economic system in the end of the 20th century, i.e. when the whole world had a centuries-old market history, in our opinion, it is advisable to classify them as new market countries.

Dependence on the previous trajectory of development led to a low level of adaptive efficiency of the system. The institutions of power and property acquired new, market-democratic forms, but there were fewer real positive changes than negative ones. The new owners did not realize that the growth of the economy they had privatized was linked to labor productivity, which, in turn, could be increased by motivated labor. The worker became hired, but the wages did not match the value of his labor. The owners of enterprises, trying to "squeeze" as much profit from production as possible, reduced costs, dooming the economy to gradual bankruptcy.

In the economy, this situation has become a pattern. As a result, the domestic economy fell into decay during the first decade of market transformation. Revenues from the sale of natural resources were used to support economic and political stability. At the same time, extractive industry enterprises were privatized with the participation of foreign investors. The share of Kazakhstan in this case ranged from 8 to 18 percent. The contracts were signed on conditions dictated by the IMF and other international organizations that lobbied for the interests of TNCs. There was no one to challenge and defend the interests of Kazakhstan: there was no competent body in the field of foreign economic activity.

An important institutional feature in the management style of the administrative-command power structures, which has become ingrained in the minds of the "new" leaders, is the setting of ambitious tasks and the ability to report on desired achievements. In modern public administration, 
this legacy is manifested in an ambitious desire to be "ahead of everyone", imitation of high achievements. It is necessary to distinguish between adequate and unrealistic ambitions. Adequate correspond to the capabilities of a person, society, they are real. Therefore, they always bring a positive result, that is, satisfaction - a person and society fulfill the set goal and feel socio-economic and political improvements in life (Sorokin, 2019).

Adequate ambition is real and is perceived positively by others. Unrealistic ambitions of the authorities can cause extremely negative emotions in society. Real ambitions are built on the capabilities and trust of the authorities and society. In this case, a social additional productive force may arise, which is capable of producing a super-perceived positive effect. When manipulating numbers that hide corruption, nepotism, raiding, promises and beliefs about a "bright future" evoke a negative reaction and protest in society.

\section{CONCLUSIONS}

To assess the degree of influence of factors reflecting the life quality of the population, a regression analysis of panel data was carried out. As a result of the econometric assessment, it was revealed that, in fact, an increase in these indicators has a small effect on economic growth. This result reveals a discrepancy between the target indicators of state programs and actual results.

Taking into account the peculiarities of Kazakhstan development as an emerging market country, it is important to define the principles of economic policy strategy and tactics.

First, we should refuse to "directly" copy the experience (not to be confused with the exchange of experience) of the historical prescription of other states. If Kazakhstan continues to move along the beaten path of more developed countries, it will remain in the rut of "always catching up with countries."

Secondly, it is necessary to openly accept the challenges of modernity, the processes of globalization with all its internal contradictions and use the accumulated potential, including intellectual, own competitive capabilities, both in the system of production factors and in the system of economic relations.

Thirdly, it is necessary to overcome innovative passivity and take into account that economic growth is the ability of multiplicative growth of all sectors and spheres of the economy. So, if in countries of a developed market, innovative activity is increasing at the expense of satellite enterprises, on which new commercial products are tested, taking into account domestic and external demand, then in Kazakhstan in 30 years there is no single large competitive industrial production with a network of venture enterprises has been created.

Fourthly, when developing models of constructive actions, one should proceed not only from the language of numbers, but to a greater extent from economic logic, understanding of cause-and-effect relationships, social and economic dependencies. The growth of labor productivity should not lead to a reduction in free working time, a deterioration in the way of life due to excessive intensity and duration of work, discrimination against women and youth, or to demographic problems. Consumption growth should not burden future income if there are no prerequisites for stable employment and sustainable income growth.

Fifth, the priority factor of economic development in the conditions of modern technological transformation is knowledge and competence, the quality of the social environment. Decent education is an indicator.

It is known that any purposeful human activity begins with an abstract representation of the image of what is being created. As the research methodology teaches: if you do not build in your mind what you create, how can you find out whether you have created it.

In this regard, the question arises as to whether the state administration has an idea of what kind of economy society creates: imitated or real, what it heals and what it adapts to.

It seems that in order to develop a concept for the development of a national economic system, knowledge should be drawn from the scientific heritage, the effective experience of foreign countries and a common understanding of goals and opportunities. Based on them, to form a "structure" around which to build all the elements of the system under construction, taking into account the accumulated 
production, economic and intellectual potential, institutional characteristics, as well as the responsibility of specific executors and controlling persons.

\section{REFERENCES}

Al'bekova, A. (2018).Dorozhnayakartazanyatostiprivela k letal'nymiskhodam. "Zakonoposlushnykh» predprinimateleyzastavlyayutplatit' za «nedobrosovestnykh» zayemshchikov [The employment roadmap has been fatal. "Law-abiding" entrepreneurs are forced to pay for "unscrupulous" borrowers]. Retrieved fromhttps://inbusiness.kz/ru/news/ABdorozhnaya-karta-zanyatosti-privela-k-letalnym-ishodam on November 19, 2020.

Auzan, A. A. (2011). Institutional economics for dummies. Moscow: Fashion Press.

Balobanov, A. E., Golubev, S. V. (2011). Kachestvozhizni-klyuchevoyparametrsovremennoystrategiimirovogogoroda [Quality of life is a key parameter of the modern strategy of the world city]. Dokladyuchastnikovyubileynogo X Obshcherossiyskogoforumaliderovstrategicheskogoplanirovaniya (17-18 oktyabrya $2011 \mathrm{~g}$, SanktPeterburg). [Reports of the participants of the jubilee X All-Russian Forum of Strategic Planning Leaders (October 17-18, 2011y, St. Petersburg)], 201. [in Russian].

Banerjee, A.V., \&Duflo, E.(2012). Poor Economics: A Radical Rethinking of the Way to Fight Global Poverty. Vintage.

Masanov, Y. (2018). Banki Kazakhstana: chto s nimi proiskhodiloposledniye 10 let.Retrieved from https://informburo.kz/stati/chto-proishodilo-s-bankami-poslednie-10-let-obyasnyaem-v-grafikah.htmlon October 10, 2020.

Chlebisz, A., \& Mierzejewski, M. (2020). Determinants of GDP growth in Scandinavian countries with special reference to scientific progress. International Entrepreneurship Review, 6(3), 21-35. https://doi.org/10.15678/IER.2020.0603.02

De Soto, H. (2004). Why capitalism triumphs in the West and is defeated in the rest of the world. Moscow: CJSC Olymp-Business.

Kapital (2020).Dostatochno li MSB gosudarstvennoypodderzhki?Retrieved from https://kapital.kz/business/89012/dostatochno-li-msb-gosudarstvennoy-podderzhki.html on October 11, 2020.

Ernst \&Young (2020). The impact of the coronavirus crisis on SMEs in Kazakhstan. Report on the results of the survey of SMEs. Ernst \& Young.

Głodowska, A., Pera, B., \& Wach, K. (2016). The International Environment and Its Influence on the Entrepreneurial Internationalization of Firms: The Case of Polish Businesses. Problemy Zarzqdzania, 14(3), 107-130. https://doi.org/10.7172/1644-9584.62.7

Głodowska, A. (2017). Business Environment and Economic Growth in the European Union Countries: What Can Be Explained for the Convergence?. Entrepreneurial Business and Economics Review, 5(4), 189-204. https://doi.org/10.15678/EBER.2017.050409

Humphreys, M., Sachs, J.D., \& Stiglitz, J.E. (Eds.) (2007). Escaping the Resource Curse. New York: Columbia University Press.

Tulekbajewa, A. (2019). Indeksschast'ya: ekspertyproverilisamochuvstviyekazakhstantsev(2019). Retrieved from https://inbusiness.kz/ru/news/indeks-schastya-eksperty-proverili-samochuvstvie-kazahstancevon September 2, 2020.

Loginova, O. (2020). Kakkoronaviruspovliyal na suitsidy $v$ mire $i v$ Kazakhstane. Retrieved from https://vlast.kz/obsshestvo/41425-celovek-naedine-s-bezdnoj.htmlon October 10, 2020.

Kursiv (2018). Kakuyurol' v ekonomike RK igrayetmalyy i sredniy biznes?Retrieved from https://kursiv.kz/news/vlasti-biznes/2018-12/kakuyu-rol-v-ekonomike-rk-igraet-malyy-i-sredniy-bizneson October 11, 2020

Kursiv (2019). Kazakhstan zanyalvtoroye mesto v YEAES po urovnyusmertnostidetey. Retrieved from https://kursiv.kz/news/obschestvo/2019-10/kazakhstan-zanyal-vtoroe-mesto-v-eaes-po-urovnyu-smertnosti-detey on October 11, 2020.

Kuznets, S. (1946). National Income: Summary of Finding. The annals of the American Academy of Political and Social Science, 250(1).

Lewis, A. W. (2013). Theory of Economic Growth. Routledge.

Marx, K. (2017). Capital: a critique of political economy. Moscow: Eksmo.

Nelson, R., \&Winter, S. (2002). Evolutionary theory of economic changes. Moscow.

Nureyev, R. M. (2008). Development economics: models of the formation of a market economy. Moscow: Norma, $367 \mathrm{p}$.

International Energy Agency (2020). Retrieved fromhttps://www.iea.org/areas-of-work/global-engagementon December 7, 2020

National Bank of Kazakhstan (2020). Retrieved fromhttps://nationalbank.kz/ru?switch=russianon December 7, 2020

Statistics Committee of the Ministry of National Economy of the Republic of Kazakhstan (2020). Retrieved from https://stat.gov.kz/on December 7, 2020 
World Bank (2020).Retrieved fromhttps://data.worldbank.org/on December 7, 2020

Sansyzbayeva, G., Temerbulatova, Z., Zhidebekkyzy, A., \&Ashirbekova, L. (2020). Evaluating the transition to green economy in Kazakhstan: A synthetic control approach. Journal of International Studies, 13(1), 324-341. https://doi.org/10.14254/2071-8330.2020/13-1/21

Schultz, T.W. (1971). Investment in Human Capital. The Role of Education and of Research. New York: The Free Press Smith, A. (2007). An Inquiry into the Nature and Causes of the Wealth of Nations. Moscow: Eksmo.

Sorokin, T. (2019). Ambitsii: stremleniyedostich' uspekhailitshcheslaviye [Ambitions: the desire to achieve success or vanity].Retrieved November 19, 2020, from http://gopsy.ru/lichnost/chto-takoe-ambicii.html.

Bocharova, M., \&Seyit, A. (2020). Statistikazanyatosti v Kazakhstane: pravdailimanipulyatsiya? Retrieved from https://factcheck.kz/socium/statistika-zanyatosti-v-kazaxstane-pravda-ili-manipulyaciya/. on October 11, 2020.

Stiglitz, J. (1997). Public Sector Economy. Moscow: Infra-M.

Todaro, M. (1997). Economic development. Moscow: Nauka.

Regnum (2020). Vsemirnyy bank prizval Kazakhstan otkazat'syaotneeffektivnykhgosprogramm. Retrieved from https://regnum.ru/news/economy/3132808.html. on December 7, 2020.

Sputnik (2017). Yunisef: deti v Kazakhstaneumirayutiz-za khalatnostiidefitsitavrachey. Retrievedfrom https://ru.sputniknews.kz/society/20171020/3547770/yunisef-deti-v-kazahstane-umirayut-iz-zahalatnosti-i-deficita-vrachej.html. on October 10, 2020.

Żak, M., \& Garncarz, J. (2020). Economic policy towards the challenges of the COVID-19 pandemic in selected European Union countries. International Entrepreneurship Review, 6(4), 21-34. https://doi.org/10.15678/IER.2020.0604.02 


\section{Authors}

The contribution share of authors is equal and amounted to $25 \%$ for each of them.

\section{MadinaTulegenova}

Associate Professor at Al-Farabi Kazakh National University (Kazakhstan). The main research specialization is the world economy.

Correspondence to: Dr. Madina Tulegenova, Al-Farabi Kazakh National University, 050040 Almaty, Kazakhstan, e-mail: ms.tulegenova17@gmail.com

ORCID (1) http://orcid.org/0000-0001-7057-8586

\section{ZhansayaTemerbulatova}

PhD Student at the Department of Economics of Al-Farabi Kazakh National University (Kazakhstan). The main research specialization is international competitiveness and green economy.

Correspondence to: ZhansayaTemerbulatova, Al-Farabi Kazakh National University, 050040 Almaty, Kazakhstan, e-mail: t.zhansaya.s@mail.ru

ORCID (1) http://orcid.org/0000-0002-3205-0948

\section{Aifer Baimukhametova}

Bachelor in Finance (2012), Master in Finance (2014). Currently PhD Student at Al-Farabi Kazakh National University (Kazakhstan).

Correspondence to: Ms. Aifer Baimukhametova, Al-Farabi Kazakh National University, 050040 Almaty, Kazakhstan, e-mail: aifer-@mail.ru

ORCID ㄴ) http://orcid.org/0000-0002-6710-415X

\section{Dinara Rakhmatullayeva}

PhD in economics. Lecturer at Al-Farabi Kazakh National University (Kazakhstan).

Correspondence to: Dr. Dinara Rakhmatullayeva, Al-Farabi Kazakh National University, Almaty, Kazakhstan, email: dintash76@gmail.com

ORCID iㅏ http://orcid.org/0000-0002-6532-1652

\section{Conflict of Interest}

The authors declare that the research was conducted in the absence of any commercial or financial relationships that could be construed as a potential conflict of interest.

\section{Copyright and License}

This article is published under the terms of the Creative Commons

Attribution - NoDerivs (CC BY-ND 4.0) License

http://creativecommons.org/licenses/by-nd/4.0/

Published by Cracow University of Economics - Krakow, Poland 